\title{
Adding aprepitant to palonosetron does not decrease carboplatin-induced nausea and vomiting in patients with gynecologic cancer
}

Yuko Watanabe ${ }^{1}$, Yoshitaka Saito ${ }^{1}$, Takashi Mitamura², Yoh Takekuma ${ }^{1}$ and Mitsuru Sugawara ${ }^{1,3^{*}}$ (D)

\begin{abstract}
Background: Recently, aprepitant has been recommended in carboplatin-based regimens, but there are limited reports on the efficacy of administering aprepitant, palonosetron, and dexamethasone (DEX) in carboplatincontaining regimens. Moreover, because aprepitant is an expensive drug, confirming its effectiveness is very important from the medical cost perspective. In this study, we examined the efficacy of prophylactically administered aprepitant, palonosetron and DEX, in paclitaxel and carboplatin (TC) combination chemotherapy.

Methods: Patients with gynecologic cancer who were treated with paclitaxel $\left(175 \mathrm{mg} / \mathrm{m}^{2}\right)$ and carboplatin (area under the curve, $A \cup C=5-6$ ) combination chemotherapy were retrospectively evaluated. The complete response (CR) rate, severity of nausea, and incidence of anorexia in the first course were compared between patients who did not receive aprepitant (control group) and those who received (aprepitant group).

Results: The 106 patients were divided into two groups, consisting of 52 and 54 the control and aprepitant groups, respectively, and the patient background showed no significant difference between both groups. The CR rate of the overall phase between the control and aprepitant groups was 73.1 vs. $74.1 \%$, that in the acute phase was 98.1 vs. $100 \%$, and in the delayed phase was 75.0 vs. $74.1 \%$, respectively, without any significant difference. The severity of nausea and incidence of anorexia were also not significantly different between both groups.

Conclusions: The results of the study suggest that adding aprepitant to palonosetron and DEX does not prevent carboplatin-induced nausea and vomiting in gynecologic cancer patients. Therefore, adding aprepitant to palonosetron does not decrease carboplatin-induced nausea and vomiting in patients with gynecologic cancer.
\end{abstract}

Keywords: Aprepitant, Carboplatin, TC, Nausea, CINV, MEC

\footnotetext{
* Correspondence: msuga@pharm.hokudai.ac.jp

'Department of Pharmacy, Hokkaido University Hospital, Kita 14-jo, Nishi

5-chome, Kita-ku, Sapporo 060-8648, Japan

${ }^{3}$ Laboratory of Pharmacokinetics, Faculty of Pharmaceutical Sciences,

Hokkaido University, Kita 12-jo, Nishi 6-chome, Kita-ku, Sapporo 060-0812,

Japan

Full list of author information is available at the end of the article
}

(C) The Author(s). 2021 Open Access This article is licensed under a Creative Commons Attribution 4.0 International License, which permits use, sharing, adaptation, distribution and reproduction in any medium or format, as long as you give appropriate credit to the original author(s) and the source, provide a link to the Creative Commons licence, and indicate if changes were made. The images or other third party material in this article are included in the article's Creative Commons licence, unless indicated otherwise in a credit line to the material. If material is not included in the article's Creative Commons licence and your intended use is not permitted by statutory regulation or exceeds the permitted use, you will need to obtain permission directly from the copyright holder. To view a copy of this licence, visit http://creativecommons.org/licenses/by/4.0/ The Creative Commons Public Domain Dedication waiver (http://creativecommons.org/publicdomain/zero/1.0/) applies to the data made available in this article, unless otherwise stated in a credit line to the data. 


\section{Introduction}

Paclitaxel and Carboplatin (TC) combination chemotherapy is regarded as the standard regimen for gynecologic cancer and, therefore, is administered to most of these patients [1-4].

Chemotherapy-induced nausea and vomiting (CINV) is one of the most frequent adverse effects, and uncontrolled CINV may limit the dose intensity of chemotherapy and decrease the patient's quality of life [5-7]. Carboplatincontaining therapies such as TC have been classified as moderate emetogenic chemotherapy (MEC). Two-drug combinations consisting of a 5-hydroxytrypatmine-3 receptor antagonist (5- $\left.\mathrm{HT}_{3} \mathrm{RA}\right)$ and dexamethasone (DEX) have been recommended with the option of adding aprepitant, which is a neurokinin-1 receptor antagonist (NK 1 RA) $[8,9]$.

However, recent guidelines for antiemetic treatments published by the Multinational Association of Supportive Care in Cancer (MASCC), European Society of Medical Oncology (ESMO), American Society of Clinical Oncology (ASCO), National Comprehensive Cancer Network $(\mathrm{NCCN})$ and the Japanese Society of Clinical Oncology (JSCO) guidelines for CINV have reclassified carboplatin [10-13]. Specifically, the drug has been reported to have the highest CINV risk in patients receiving MEC, and the guidelines suggest the administration of antiemetics according to the recommendations for the highly emetogenic chemotherapy (HEC) classification [10-13]. Aprepitant has been shown to be effective for CINV when added to $5-\mathrm{HT}_{3} \mathrm{RAs}$ and DEX in HEC and MEC regimens [1418]. However, previous studies have reported that adding aprepitant to conventional therapies does not prevent CINV during the first carboplatin administration [19-21]. Furthermore, although palonosetron is preferred to firstgeneration $5-\mathrm{HT}_{3} \mathrm{RAs}$ such as granisetron or ondansetron for MEC or HEC [22, 23], there are few reports on the efficacy of aprepitant, palonosetron, and DEX in carboplatin-containing regimens $[5,6,14,15]$. In particular, being a member of the female sex is known to be a risk factor for CINV [18], making the efficacy of this agent in gynecologic cancer patients controversial. Moreover, because aprepitant is an expensive medicine, it is important to confirm its effectiveness from the perspective of the medical cost [24-26].

In this study, we evaluated the efficacy of prophylactic administration of aprepitant, palonosetron, and DEX as part of a carboplatin-based regimen.

\section{Patients and methods}

\section{Patients}

Patients who received the combination chemotherapy regimen of paclitaxel $\left(175 \mathrm{mg} / \mathrm{m}^{2}\right)$ and carboplatin (area under the curve; AUC =5-6) every 3-4 weeks as a first line chemotherapy for gynecologic cancer from January
2015 to June 2019 were enrolled in this retrospective study.

Patients were divided into two groups, consisting of one that did not receive aprepitant from January 2015 to June 2017 (control), and another that did receive aprepitant from July 2017 to June 2019 (aprepitant group). Patients who experienced uncontrolled nausea and vomiting or were regularly administered antiemetic drugs such as metoclopramide, domperidone, lorazepam, prochlorperazine, and patients with insufficient data were excluded. This retrospective study was approved by the Institutional Review Board of the Hokkaido University Hospital (approval number: 018-0390) and conducted in accordance with the Declaration of Helsinki. In view of the retrospective nature of the study, informed consent from the subjects was not mandated.

\section{Treatment methods}

Patients in the control group were treated with palonosetron $0.75 \mathrm{mg}$ and DEX $16.5 \mathrm{mg}$ intravenously on day 1 , and DEX $8 \mathrm{mg}$ orally on day 2-3. Patients in the aprepitant group were treated with aprepitant $125 \mathrm{mg}$ orally, palonosetron $0.75 \mathrm{mg}$, and DEX $16.5 \mathrm{mg}$ intravenously on day 1 , followed by aprepitant $80 \mathrm{mg}$ and DEX $4 \mathrm{mg}$ orally on day $2-3$. Antiemetic drugs such as metoclopramide domperidone or prochlorperazine were administered as rescue medications according to the physician's decision.

\section{Evaluation criteria}

All patients were hospitalized, and the required information was obtained from their daily medical records. In the evaluation period, day $1-5$, day 1 , and day $2-5$ were defined as the overall, acute, delayed phases at the first implementation of TC as described previously [27]. The primary endpoint was a complete response (CR), which was defined as the absence of emetic events, vomiting, and need for rescue antiemetic treatment in the overall phase. Secondary endpoints were configured the CR rate in the acute and delayed phase, the severity of nausea, and the prevalence of anorexia. The symptoms of CINV were evaluated based on the real-time assessment of daily physicians and/or pharmacists according to Common Terminology Criteria for Adverse Events version 4.0, when the patients were hospitalized.

\section{Statistical analysis}

The differences in patient background between the control and aprepitant groups were assessed using Fisher's exact probability test for categorical outcome variables, and the Mann-Whitney $U$ test for the continuous parameters. Differences in the CR rate and incidence of anorexia between the two groups were analyzed using Fisher's exact probability test. Differences in the degree 
of severity of nausea were assessed using the MannWhitney U test. All analyses were carried out using the JMP version 14.0 statistical software (SAS Institute Japan, Tokyo, Japan). A significant difference was accepted for results with a $P$-value $<0.05$ for all tests.

\section{Results}

\section{Patients}

A total of 140 patients were enrolled in this study, including 34 who were excluded during screening. Then, 106 patients were divided into two groups, consisting of 52 and 54 patients in the control and aprepitant group, respectively (Fig. 1). Patients' background information is shown in Table 1. There was no significant difference between the control and aprepitant groups in age, performance status, cancer diagnosis, staging, chemotherapy setting, body surface area, drinking habit, and TC dosage. The proportion of patients who were administered carboplatin at a dose of $\mathrm{AUC}=5$ was $100 \%$ in the control group and 98.1\% in the aprepitant group, and that of patients administered at a dose of AUC $=6$ was 0 and $1.9 \%$ in the control and aprepitant groups, respectively, without significant differences. Patients with renal dysfunction (grade 1 or higher serum creatinine elevation), and those with liver dysfunction (grade 1 or higher aspartate transaminase, alanine aminotransferase, and total bilirubin elevation) were not different between the groups. There were no patients with grade 2 or higher adverse events.

\section{Comparison of $\mathrm{CR}$ rate}

The CR rate of the overall phase was 73.1 and $74.1 \%$ in the control and aprepitant groups, respectively and there was no statistically significant difference $(P=1.00$, Fig. 2$)$. The CR rate in the acute and delayed phase are also shown in Fig. 3. The CR rate of the acute phase was 98.1 and $100 \%$ in the control and aprepitant groups, respectively and the corresponding values of the delayed phase were 75.0 and $74.1 \%$, respectively. Furthermore, there were no statistically significant differences between the

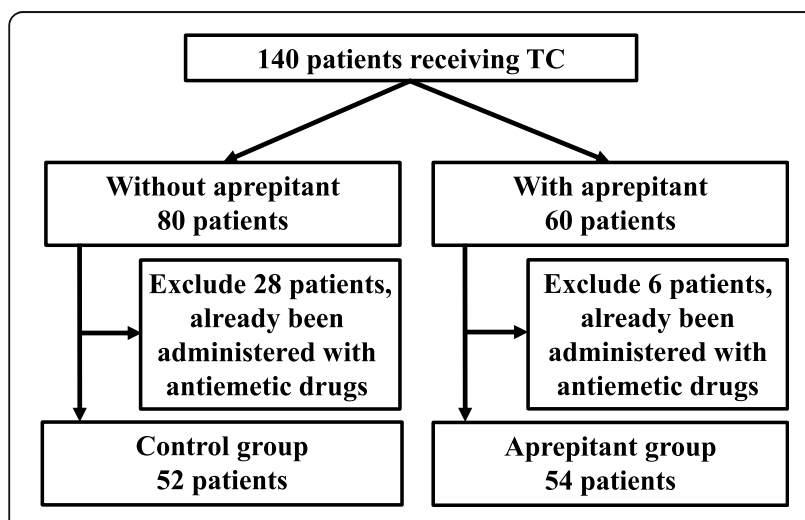

Fig. 1 Study flow chart. TC: paclitaxel and carboplatin
Table 1 Patients' background

\begin{tabular}{|c|c|c|c|}
\hline & $\begin{array}{l}\text { Control group } \\
\quad(n=52)\end{array}$ & $\begin{array}{l}\text { Aprepitant group } \\
\quad(n=54)\end{array}$ & $P$-value \\
\hline Age (median, range) & $59(29-83)$ & $58(38-81)$ & 0.70 \\
\hline $\begin{array}{l}\text { Performance status (ECOG) } \\
0-1 / 2-3\end{array}$ & $51 / 1$ & $53 / 1$ & 1.00 \\
\hline \multicolumn{4}{|l|}{ Cancer diagnosis (number, \%) } \\
\hline Ovarian or tubal cancer & $17(32.7)$ & $22(40.7)$ & 0.43 \\
\hline Uterine cancer & $28(53.8)$ & $28(51.9)$ & 0.85 \\
\hline Cervical cancer & $6(11.5)$ & $1(1.9)$ & 0.06 \\
\hline Vaginal cancer & $0(0)$ & $1(1.9)$ & 1.00 \\
\hline Double cancer & $1(1.9)$ & $2(3.7)$ & 1.00 \\
\hline \multicolumn{4}{|l|}{ Staging (number, \%) } \\
\hline$|/||/|||$ & $39(75.0)$ & $39(72.2)$ & 0.83 \\
\hline IV/recurrence & $13(25.0)$ & $15(27.8)$ & \\
\hline \multicolumn{4}{|l|}{ Chemotherapy setting } \\
\hline neoadjuvant or adjuvant & $44(84.6)$ & $49(90.7)$ & 0.34 \\
\hline for advanced cancer & $8(15.4)$ & $5(9.3)$ & \\
\hline $\begin{array}{l}\text { Height }(\mathrm{cm}) \\
\text { (median, range) }\end{array}$ & $155.5(144.6-172.1)$ & $154.2(142.0-169.5)$ & 0.49 \\
\hline $\begin{array}{l}\text { Body weight }(\mathrm{kg}) \\
\text { (median, range) }\end{array}$ & $54.7(35.6-84.6)$ & $54.3(37.7-89.2)$ & 0.79 \\
\hline $\begin{array}{l}\text { Body surface area }\left(\mathrm{m}^{2}\right) \\
\text { (median, range) }\end{array}$ & $1.53(1.24-1.85)$ & $1.54(1.21-1.87)$ & 0.90 \\
\hline Drinking habit (number, \%) & $24(46.2)$ & $21(38.9)$ & 0.57 \\
\hline \multicolumn{4}{|c|}{ Carboplatin dosage (AUC) (number, \%) } \\
\hline 5 & $52(100)$ & $53(98.1)$ & 1.00 \\
\hline 6 & $0(0)$ & $1(1.9)$ & \\
\hline $\begin{array}{l}\text { Paclitaxel dosage (mg) } \\
\text { (median, range) }\end{array}$ & $261.7(220-320)$ & $266.8(210-325)$ & 0.43 \\
\hline $\begin{array}{l}\text { Dose reduction } \\
\text { (number, \%) }\end{array}$ & $3(5.8)$ & $1(1.9)$ & 0.36 \\
\hline $\begin{array}{l}\text { Renal dysfunction } \\
\text { (number, \%) }\end{array}$ & $4(7.6)$ & $5(9.3)$ & 1.00 \\
\hline $\begin{array}{l}\text { Liver dysfunction } \\
\text { (number, \%) }\end{array}$ & $9(17.3)$ & $12(22.2)$ & 0.63 \\
\hline
\end{tabular}

Renal dysfunction: grade 1 or higher serum creatinine elevation Liver dysfunction: grade 1 or higher aspartate transaminase, alanine aminotransferase, and total bilirubin elevation

$A \cup C$ area under the carve

groups $(P=0.49$ and 1.00 , respectively). In the control group, $26.9 \%$ of the patients were administered the rescue dose, whereas, $24.1 \%$ of those in the aprepitant group were administered the rescue dose, without significant differences $(P=0.82)$.

\section{Comparison of severity of nausea}

Table 2 shows the comparison of the severity of nausea between the groups, and the results indicate that there was no statistically significant difference in the acute and delayed phases.

\section{Comparison of incidence of anorexia}

All anorexia appeared in the delayed phase, and its incidence was not statistically different between the control 


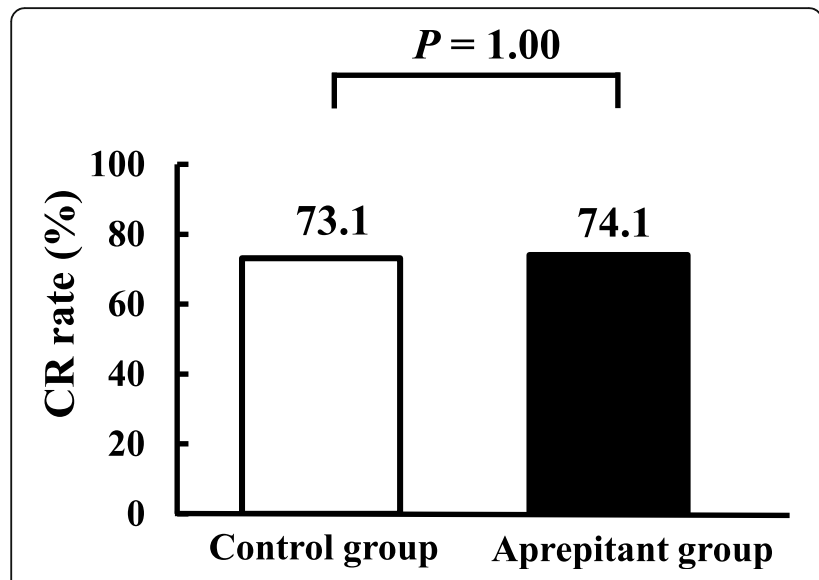

Fig. $\mathbf{2}$ Complete response (CR) rate in overall phase

and aprepitant groups, at 38.5 and $37.0 \%$, respectively $(P=1.00$, Fig. 4).

\section{Discussion}

Most of patients with gynecologic cancer are treated with a carboplatin-containing chemotherapy regimen [1-4]. CINV is one of the most serious side effects in cancer patients, therefore, its control is important to maintain patients' quality of life and ensure continuation of chemotherapy [5-7]. Previous studies have recommended the addition of aprepitant to carboplatincontaining chemotherapy $[5,6,13-18,22,23]$. In particular, because female sex is a known risk factor for CINV [18], it would be important to evaluate its efficacy in gynecologic cancer patients. Therefore, we evaluated the efficacy of prophylactic administration of aprepitant, palonosetron, and DEX in carboplatin-based regimens in gynecologic cancer.

The results showed that the CR rate of the overall, acute, and delayed phases was not significantly different between the control and aprepitant group. Moreover, the severity of nausea and incidence of anorexia were not different between the groups. These results suggest that adding aprepitant did not attenuate CINV induced by carboplatin-containing regimens in gynecologic cancer.

In addition, medical care expenses for citizens have been increasing, and it is a concern with the use of aprepitant [24-26], therefore, its addition should be reconsider. Aprepitant is a high-priced drug, and the original branded drug cost 8949.3 Japanese yen (JPY), whereas generic drugs are 4511.2 JPY for a 3 day course. Fosaprepitant for intravenous infusion costs 13,978 JPY. The drug cost for a patient who receives six courses of a carboplatin-containing chemotherapy regimen, would be 53,695.8 JPY for the original bland name drug, 27,067.2 JPY for the generic agent, and 83,868 JPY for fosaprepitant. Carboplatin-containing regimens are generally administered as outpatient chemotherapy; thus, the drug cost directly affects the healthcare cost. As the use of additional rescue dose was similar between the groups, the medical cost in the aprepitant group might be higher than that in the control group. Further increases in the burden of health care expense are expected with the increase in cancer patients. From the viewpoint of health economy, aprepitant administration in carboplatincontaining chemotherapy regimens may need to be reconsidered.

Furthermore, the potential for interactions between aprepitant and other medications should be noted, because aprepitant is an inhibitor or inducer of CYP3A4 and an inducer of CYP2C9 [28-30]. Owing to the moderate inhibition of CYP3A4 by aprepitant, the metabolism of DEX, which is a CYP3A4 substrate, is decreased, leading to a 2.2-fold increase in the AUC of DEX and the guidelines recommend decreasing the dose of DEX by $50 \%$ when it is combined with aprepitant $[28,29]$. In contrast, the metabolism of warfarin, which is a CYP2C9 substrate, is increased by aprepitant, resulting in a decrease in the international normalized ratio (INR); therefore, frequent INR monitoring is recommended for 2-3 weeks [30]. Because cancer patients often take multiple

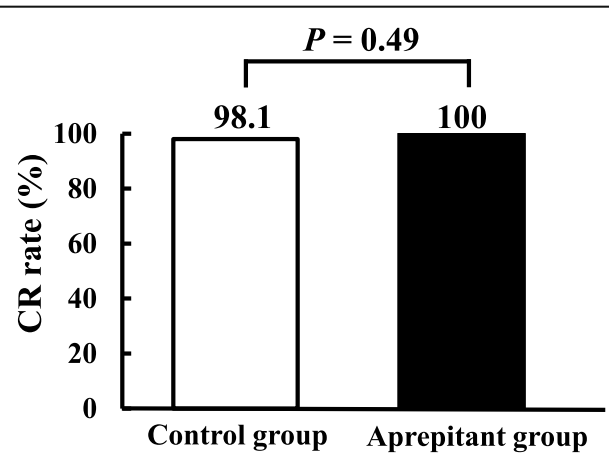

(a) acute phase

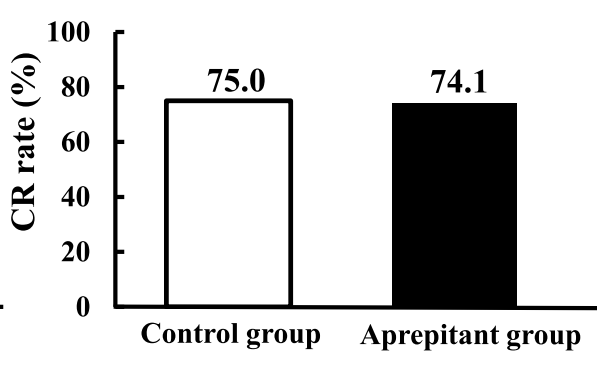

(b) delayed phase

Fig. 3 Complete response (CR) rate in (a) acute and (b) delayed phases 
Table 2 Severity of nausea

\begin{tabular}{|c|c|c|c|c|c|c|c|}
\hline & \multicolumn{3}{|c|}{ Control group $(n=52)$} & \multicolumn{3}{|c|}{ Aprepitant group $(n=54)$} & \multirow{2}{*}{$\begin{array}{c}P- \\
\text { value }\end{array}$} \\
\hline & Grade 0 & Grade 1 & Grade 2 & Grade 0 & Grade 1 & Grade 2 & \\
\hline Acute phase & 51 & 1 & 0 & 54 & 0 & 0 & 0.32 \\
\hline Delayed phase & 39 & 9 & 4 & 40 & 8 & 6 & 0.85 \\
\hline
\end{tabular}

medicines, drug-drug interaction is one of the treatment challenges. Moreover, there is a risk of the patient forgetting to take aprepitant and infusion-site reactions caused by fosaprepitant [31].

Sugimori et al. have reported that the CR rate in the delayed phase was higher in the aprepitant group than in the control group, suggesting the usability of aprepitant [32]. A difference between our study and previous study is the DEX dosage on day 1 . In the previous study, antiemetic therapy on day 1 was $13.2 \mathrm{mg}$ DEX in the control group and $6 \mathrm{mg}$ DEX in the aprepitant group, whereas that in our study was $16.5 \mathrm{mg}$ in both groups. It is known that paclitaxel induces a hypersensitivity reaction; therefore, high-dose DEX administration is necessary according to the package insert. We consider that high-dose DEX administration on day 1 counteracted the effect of aprepitant in this study. We consider that this difference is important and reflects the situation in real-world clinical setting.

In our study, we used palonosetron as $5-\mathrm{HT}_{3} \mathrm{RA}$, but based on the drug cost, the first-generation $5-\mathrm{HT}_{3} \mathrm{RAs}$ are better than palonosetron in the HEC regimens [26]. Moreover, there are reports that granisetron produces an equivalent $C R$ rate to that of palonosetron in the overall phase [5]. However, some studies have reported that palonosetron is more effective than the firstgeneration $5-\mathrm{HT}_{3} \mathrm{RA}$ agents $[15,22,23]$. Furthermore, it has been reported that 1 day and 3 days DEX administration with $0.75 \mathrm{mg}$ palonosetron on day 1 have comparable antiemetic efficacy [33]. The combination of antiemetic drugs should be selected after considering their antiemetic efficacy and drug cost.

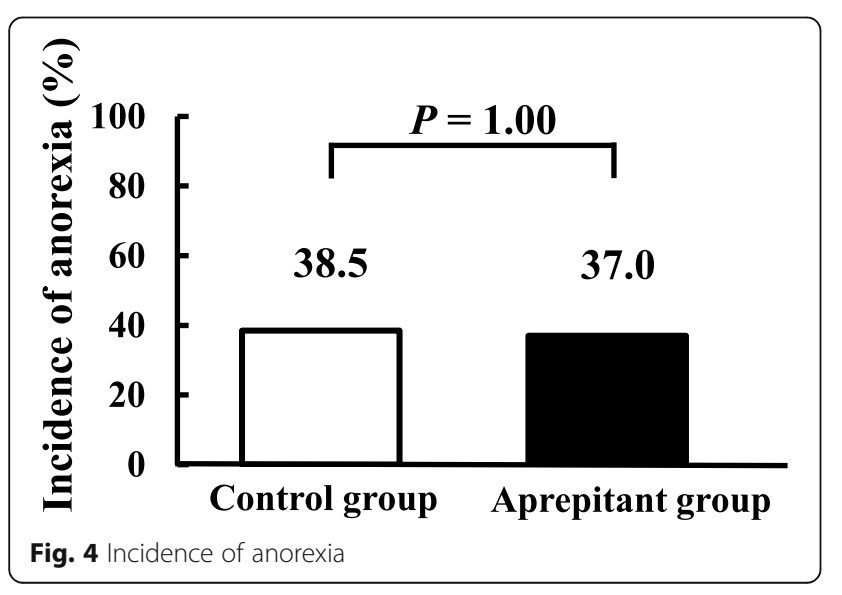

There are some limitations to the current study. First, this study was a retrospective review with a relatively small population. We were not able to evaluate the presence of motion sickness in baseline characteristics. Therefore, it would be necessary to perform a large-scale randomized prospective study to verify these results. Second, patients in this study were all female with gynecologic cancer and it would be better to make comparisons in a well-balanced population. Third, we evaluated the efficacy of aprepitant in the first course because several factors may affect CINV in the subsequent courses. Evaluation in multiple courses of chemotherapy may reveal other outcomes, thus warranting further research. Finally, we adopted a healthcare worker-based evaluation of CINV in this retrospective study; however, a subjective assessment by patients would provide a better evaluation of the antiemetic therapy.

\section{Conclusions}

Our findings suggest that adding aprepitant to palonosetron and DEX does not prevent carboplatin-induced nausea and vomiting in gynecologic cancer patients. Therefore, adding aprepitant to palonosetron does not decrease carboplatin-induced nausea and vomiting in patients with gynecologic cancer.

\section{Acknowledgements \\ None.}

Authors' contributions

Participated in research design: YW, YS and YT. Conducted experiments: YW. Performed data analysis: YW, YS. Wrote or contributed to the writing of the manuscript: YW, YS, TM, YT and MS. The author(s) read and approved the final manuscript.

Funding

None.

Availability of data and materials

All data generated or analyzed in this study are included within the article.

\section{Declarations}

Ethics approval and consent to participate

This retrospective study was approved by the Institutional Review Board of the Hokkaido University Hospital (approved number: 018-0390). All the procedures performed in studies involving human participants were out in accordance with the ethical standards of the institutional and/or national research committee and with the 1964 Helsinki declaration and its later amendments or comparable ethical standards. For this type of study, formal consent is not required.

Consent for publication Not applicable. 


\section{Competing interests}

The authors declare no conflicts of interest associated with this manuscript.

\section{Author details}

'Department of Pharmacy, Hokkaido University Hospital, Kita 14-jo, Nishi 5-chome, Kita-ku, Sapporo 060-8648, Japan. ${ }^{2}$ Department of Obstetrics and Gynecology, Faculty of Medicine and Graduate School of Medicine, Hokkaido University, Kita 15-jo, Nishi 7-chome, Kita-ku, Sapporo, Hokkaido 060-8648, Japan. ${ }^{3}$ Laboratory of Pharmacokinetics, Faculty of Pharmaceutical Sciences, Hokkaido University, Kita 12-jo, Nishi 6-chome, Kita-ku, Sapporo 060-0812, Japan

Received: 28 December 2020 Accepted: 3 April 2021 Published online: 01 June 2021

\section{References}

1. Kitagawa R, Katsumata N, Shibata T, Kamura T, Kasamatsu T, Nakanishi T, et al. Paclitaxel plus carboplatin versus paclitaxel plus cisplatin in metastatic or recurrent cervical cancer: the open-label randomized phase III trial JCOG0505. J Clin Oncol. 2015;33(19):2129-35. https://doi.org/10.1200/JCO.2 014.58 .4391

2. Lorusso D, Petrelli F, Coinu A, Raspagliesi F, Barni S. A systematic review comparing cisplatin and carboplatin plus paclitaxel-based chemotherapy for recurrent or metastatic cervical cancer. Gynecol Oncol. 2014;133(1):117-23. https://doi.org/10.1016/j.ygyno.2014.01.042.

3. du Bois A, Lück HJ, Meier W, Adams HP, Möbus V, Costa S, et al. A randomized clinical trial of cisplatin/paclitaxel versus carboplatin/paclitaxel as first-line treatment of ovarian cancer. J Natl Cancer Inst. 2003;95(17): 1320-9. https://doi.org/10.1093/jnci/djg036.

4. Mabuchi S, Morishige K, Fujita M, Tsutsui T, Sakata M, Enomoto T, et al. The activity of carboplatin and paclitaxel for recurrent cervical cancer after definitive radiotherapy. Gynecol Oncol. 2009;133:200-4.

5. Fujiwara S, Terai Y, Tsunetoh S, Sasaki H, Kanemura M, Ohmichi M. Palonosetron versus granisetron in combination with aprepitant for the prevention of chemotherapy-induced nausea and vomiting in patients with gynecologic cancer. J Gynecol Oncol. 2015;26(4):311-9. https://doi.org/10.3 802/jgo.2015.26.4.311.

6. Yoshida N, Taguchi T, Nakanishi M, Inoue K, Okayama T, Ishikawa T, et al. Efficacy of the combination use of aprepitant and palonosetron for improving nausea in various moderately emetogenic chemotherapy regimens. BMC Pharmacol Toxicol. 2019;20(1):6. https://doi.org/10.1186/s403 60-018-0278-2

7. Karayama M, Inui N, Tanaka K, Yasui H, Hozumi H, Suzuki Y, et al. Prophylactic aprepitant is better than salvage for carboplatin-based chemotherapy: a propensity score-matched analysis. Med Oncol. 2018; 35(11):139. https://doi.org/10.1007/s12032-018-1199-z.

8. Roila F, Herrstedt J, Aapro M, Gralla RJ, Einhorn LH, Ballatori E, et al. Guideline update for MASCC and ESMO in the prevention of chemotherapy- and radiotherapy-induced nausea and vomiting: Results of the Perugia consensus conference. Ann Oncol. 2010;21(Supplement 5): v232-43.

9. Basch E, Prestrud AA, Hesketh PJ, Kris MG, Feyer PC, Somerfield MR, et al. Antiemetics: American Society of Clinical Oncology clinical practice guideline update. J Clin Oncol. 2011;29(31):4189-98. https://doi.org/10.1200/ JCO.2010.34.4614

10. Roila F, Molassiotis A, Herrstedt J, Aapro M, Gralla RJ, Bruera E, et al. 2016 MASCC and ESMO guideline update for the prevention of chemotherapyand radiotherapy-induced nausea and vomiting and of nausea and vomiting in advanced cancer patients. Ann Oncol. 2016;27(suppl 5):v119-33. https://doi.org/10.1093/annonc/mdw270.

11. Hesketh PJ, Kris MG, Basch E, Bohlke K, Barbour SY, Clark-Snow RA, et al. Antiemetics: American Society of Clinical Oncology clinical practice guideline update. J Clin Oncol. 2017;35(28):3240-61. https://doi.org/10.1200/ JCO.2017.74.4789.

12. Berger MJ, Ettinger DS, Aston J, Barbour S, Bergsbaken J, Bierman PJ, et al. NCCN Guidelines Insights: Antiemesis, Version 2.2017. J Natl Compr Cancer Netw. 2017;15:883-93.

13. Aogi K, Takeuchi H, Saeki T, Aiba K, Tamura K, lino K, et al. Optimizing antiemetic treatment for chemotherapy-induced nausea and vomiting in Japan: Update summary of the 2015 Japan Society of Clinical Oncology Clinical Practice Guidelines for antiemesis. Int J Clin Oncol. 2021;26(1):1-17.
14. Micha JP, Rettenmaier MA, Brown JV, Mendivil A, Abaid LN, Lopez KL, et al. A Randomized Controlled Pilot Study Comparing the Impact of Aprepitant and Fosaprepitant on Chemotherapy Induced Nausea and Vomiting in Patients Treated for Gynecologic Cancer. Int J Gynecol Cancer. 2016;26(2): 389-93. https://doi.org/10.1097/IGC.0000000000000593.

15. Yokoe T, Hayashida T, Nagayama A, Nakashoji A, Maeda H, Seki T, et al. Effectiveness of antiemetic regimens for highly emetogenic chemotherapyinduced nausea and vomiting: a systematic review and network metaanalysis. Oncologist. 2019;24(6):e347-57. https://doi.org/10.1634/ theoncologist.2018-0140.

16. Maehara M, Ueda T, Miyahara D, Takahashi Y, Miyata K, Nam SO, et al. Clinical efficacy of aprepitant in patients with gynecological cancer after chemotherapy using paclitaxel and carboplatin. Anticancer Res. 2015;35(8): 4527-34.

17. Schwartzberg LS, Marks SM, Gabrail NY, Geller RB, Kish J. Real-world effectiveness of palonosetron-based antiemetic regimens: preventing chemotherapy-induced nausea and vomiting. J Comp Eff Res. 2019:8(9): 657-70. https://doi.org/10.2217/cer-2018-0104.

18. Yahata H, Kobayashi H, Sonoda K, Shimokawa M, Ohgami T, Saito T, et al. Efficacy of aprepitant for the prevention of chemotherapy-induced nausea and vomiting with a moderately emetogenic chemotherapy regimen: a multicenter, placebo-controlled, double-blind, randomized study in patients with gynecologic cancer receiving paclitaxel and carboplatin. Int J Clin Oncol. 2016;21(3):491-7. https://doi.org/10.1007/s10147-015-0928-y.

19. Takeuchi M, Goto A, Tsubai T, Hida H, Mukoyama N, Otsuka M. The effectiveness of aprepitant for gastrointestinal symptoms induced by highly and moderately emetogenic platinum-containing drugs. Jpn J Pharm Palliat Care Sci. 2014;7:105-10.

20. lihara H, Ishihara M, Fujii H, Yoshimi C, Yamada M, Suzuki A, et al. Comparison of the control of nausea and vomiting among several moderately emetic-risk chemotherapy regimens. J Cancer. 2016;7(5):569-75. https://doi.org/10.7150/jca.13637.

21. Kusagaya H, Inui N, Karayama M, Fujisawa T, Enomoto N, Kuroishi S, et al. Evaluation of palonosetron and dexamethasone with or without aprepitant to prevent carboplatin-induced nausea and vomiting in patients with advanced non-small-cell lung cancer. Lung Cancer. 2015;90(3):410-6. https://doi.org/10.1016/j.lungcan.2015.11.009.

22. Suzuki K, Yamanaka T, Hashimoto H, Shimada Y, Arata K, Matsui R, et al. Randomized, double-blind, phase III trial of palonosetron versus granisetron in the triplet regimen for preventing chemotherapy-induced nausea and vomiting after highly emetogenic chemotherapy: TRIPLE study. Ann Oncol. 2016;27(8):1601-6. https://doi.org/10.1093/annonc/mdw220.

23. Popovic M, Warr DG, Deangelis C, Tsao M, Chan KK, Poon M, et al. Efficacy and safety of palonosetron for the prophylaxis of chemotherapy-induced nausea and vomiting (CINV): a systematic review and meta-analysis of randomized controlled trials. Support Care Cancer. 2014;22(6):1685-97. https://doi.org/10.1007/s00520-014-2175-6.

24. Tsukiyama I, Hasegawa S, Ikeda Y, Takeuchi M, Tsukiyama S, Kurose Y, et al. Cost-effectiveness of aprepitant in Japanese patients treated with cisplatincontaining highly emetogenic chemotherapy. Cancer Sci. 2018;109(9):28818. https://doi.org/10.1111/cas.13736.

25. Abe T, Yokoyama T, Kurokawa Y, Hayabe H, Miyasato A, Osato Y, et al. Proper use of antiemetic drugs in an outpatient chemotherapy center. J Tokyo Med Univ. 2012;70:15-25.

26. Shimizu H, Suzuki K, Uchikura T, Tsuji D, Yamanaka T, Hashimoto H, et al. Economic analysis of palonosetron versus granisetron in the standard triplet regimen for preventing chemotherapy-induced nausea and vomiting in patients receiving highly emetogenic chemotherapy in Japan (TRIPLE phase III trial). J Pharm Health Care Sci. 2018;4:31. https://doi.org/10.1186/s40780018-0128-9.

27. Sakamoto T, Saito Y, Kobayashi M, Yamada T, Takekuma Y, Nakai M, et al. Effect of palonosetron and dexamethasone administration on the prevention of gastrointestinal symptoms in hepatic arterial chemoembolization with epirubicin. Support Care Cancer. 2020;28(7):32517. https://doi.org/10.1007/s00520-019-05178-1.

28. Schoffelen $R$, Lankheet $A G$, van Herpen $C M L$, van der Hoeven JJM, Desar IME, Kramers C. Drug-drug interactions with aprepitant in antiemetic prophylaxis for chemotherapy. Neth J Med. 2018;76(3):109-14.

29. McCrea JB, Majumdar AK, Goldberg MR, Iwamoto M, Gargano C, Panebianco DL, et al. Effects of the neurokinin1 receptor antagonist aprepitant on the pharmacokinetics of dexamethasone and 
methylprednisolone. Clin Pharmacol Ther. 2003;74(1):17-24. https://doi.org/1 0.1016/50009-9236(03)00066-3.

30. Depré M, Van Hecken A, Oeyen M, De Lepeleire I, Laethem T, Rothenberg P, et al. Effect of aprepitant on the pharmacokinetics and pharmacodynamics of warfarin. Eur J Clin Pharmacol. 2005;61(5-6):341-6. https://doi.org/10.1 007/s00228-005-0907-8.

31. Lundberg JD, Crawford BS, Phillips G, Berger MJ, Wesolowski R. Incidence of infusion-site reactions associated with peripheral intravenous administration of fosaprepitant. Support Care Cancer. 2014;22(6):1461-6. https://doi.org/1 0.1007/s00520-013-2106-y.

32. Sugimori $Y$, Ota T, Ujihira T, Ishiguro T, Ogishima D. A phase II randomized study to evaluate the efficacy of aprepitant plus palonosetron for preventing delayed-phase CINV associated with TC therapy in gynaecological cancer. J Obstet Gynaecol Res. 2017;43(9):1454-9. https://doi. org/10.1111/jog.13378.

33. Komatsu Y, Okita K, Yuki S, Furuhata T, Fukushima H, Masuko H, et al. Openlabel, randomized, comparative, phase III study on effects of reducing steroid use in combination with Palonosetron. Cancer Sci. 2018;106:891-5.

\section{Publisher's Note}

Springer Nature remains neutral with regard to jurisdictional claims in published maps and institutional affiliations.

Ready to submit your research? Choose BMC and benefit from:

- fast, convenient online submission

- thorough peer review by experienced researchers in your field

- rapid publication on acceptance

- support for research data, including large and complex data types

- gold Open Access which fosters wider collaboration and increased citations

- maximum visibility for your research: over $100 \mathrm{M}$ website views per year

At BMC, research is always in progress.

Learn more biomedcentral.com/submissions 